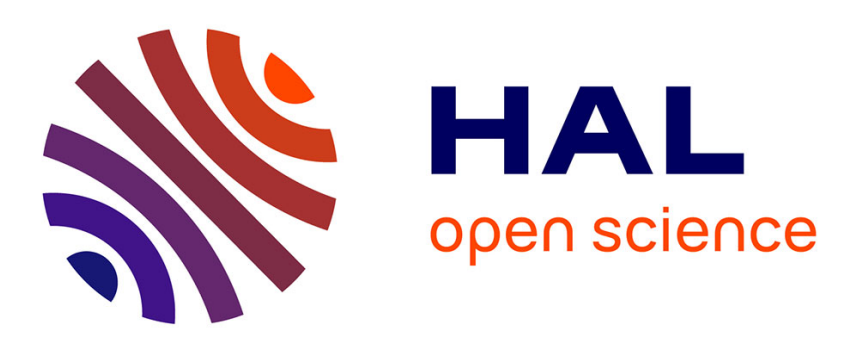

\title{
Comparison of adsorption systems using natural gas fired fuel cell as heat source, for residential air conditioning
}

\author{
Marc Clausse, Frédéric Meunier, Julien Coulié, Elodie Herail
}

\section{To cite this version:}

Marc Clausse, Frédéric Meunier, Julien Coulié, Elodie Herail. Comparison of adsorption systems using natural gas fired fuel cell as heat source, for residential air conditioning. International Journal of Refrigeration, 2009, 32 (4), pp.712-719. 10.1016/j.ijrefrig.2009.01.009 hal-02078634

\section{HAL Id: hal-02078634 \\ https://hal.science/hal-02078634}

Submitted on 25 Mar 2019

HAL is a multi-disciplinary open access archive for the deposit and dissemination of scientific research documents, whether they are published or not. The documents may come from teaching and research institutions in France or abroad, or from public or private research centers.
L'archive ouverte pluridisciplinaire HAL, est destinée au dépôt et à la diffusion de documents scientifiques de niveau recherche, publiés ou non, émanant des établissements d'enseignement et de recherche français ou étrangers, des laboratoires publics ou privés. 


\title{
COMPARISON OF ADSORPTION SYSTEMS USING NATURAL GAS FIRED FUEL CELL AS HEAT SOURCE, FOR RESIDENTIAL AIR CONDITIONING
}

\author{
M. Clausse ${ }^{1^{*}}$, F. Meunier ${ }^{1}$
}

\section{J. Coulié ${ }^{2}$ E. Herail ${ }^{2}$}

\author{
1: LGP2ES, Cnam-IFFI (EA21), case 331, \\ 292 rue Saint-Martin, 75141 Paris Cedex 03, France; \\ * corresponding author: e-mail: marc.clausse@cnam.fr, \\ tel: (+33) (0)1 588085 49, fax: (+33) (0)1 40272047 \\ 2: N-GHY, Site Industriel Saint Antoine - ZI Montplaisir \\ 51 rue Isaac Newton, 81000 Albi, France \\ tel: (+33) (0)5 634573 70, e-mail: elodie.herail@n-ghy.com
}

\begin{abstract}
This article aim is to evaluate the performances of an adsorption system driven thanks to the heat rejected by the post-combustion exhaust gases of a reformer/fuel cell system for residential air-conditioning application. Three adsorption pairs were compared: activated carbon/methanol, silica gel/water and zeolite/water. Taking into account both cooling power and sensitivity to performances of the heat rejection and recovery exchangers, it appears that zeolite $13 \mathrm{X} /$ water is
\end{abstract}


the adsorption pair giving the best performance for this application. Nevertheless, a more detailed model would be of interest to better quantify the heat transfer impact on performance.

Keywords: adsorption, residential air-conditioning, fuel cell, combined heat and power (CCHP)

\section{NOMENCLATURE}

c, $\mathrm{C}_{\mathrm{p}}$

COP

$\mathrm{D}$

$\Delta \mathrm{H}$

L

$\mathrm{M}$

$\dot{\mathrm{m}}$

$\mathrm{n}$

$\mathrm{P}$

q

$\dot{\mathrm{Q}}$

$\mathrm{T}$

UA

Greek

$\lambda$

$\rho$

subscripts

0

a

ads specific heat capacity

$\left(\mathrm{J} \cdot \mathrm{kg}^{-1} \cdot \mathrm{K}^{-1}\right)$

Coefficient of Performance

Coefficient in Dubinin Astakov eq. (1)

heat of adsorption

heat of vaporization

mass

mass flow rate

Coefficient in Dubinin Astakov eq. (1)

pressure

adsorption capacity

heat flux

temperature

overall heat transfer coefficient

$(-)$

$\left(\mathrm{K}^{-1}\right)$

$\left(J \cdot \mathrm{kg}^{-1}\right)$

$\left(J \cdot \mathrm{kg}^{-1}\right)$

(kg)

$\left(\mathrm{kg} \cdot \mathrm{s}^{-1}\right)$

$(-)$

(Pa)

$\left(\mathrm{kg} \mathrm{kg}_{\mathrm{ads}}{ }^{-1}\right)$

(W)

(K)

$\left(\mathrm{W} \cdot \mathrm{K}^{-1}\right)$

$\left(\mathrm{W} \cdot \mathrm{m}^{-1} \cdot \mathrm{K}^{-1}\right)$

density

$\left(\mathrm{kg} . \mathrm{m}^{-3}\right)$

saturation

adsorber

adsorbent 


$\begin{array}{ll}\text { cd } & \text { condenser } \\ \text { CW } & \text { chilled water } \\ \text { d } & \text { desorber } \\ \text { ev } & \text { evaporator } \\ \text { fl } & \text { adsorbate } \\ \text { gas } & \text { fuel cell exhaust gases } \\ \text { HW } & \text { hot water } \\ \text { l } & \text { liquid } \\ \text { met } & \text { metal } \\ \text { v } & \text { volumic } \\ \text { v } & \text { vapor } \\ \text { Wrej } & \text { heat rejection unit fluid }\end{array}$

\section{INTRODUCTION}

Compared to classical cogeneration systems, fuel cells can prevail from various advantages for residential applications: low noise level, potential for low maintenance, excellent part load management, low emissions and a potential to achieve an overall efficiency of 85-90\% even with small units (Onovwiona and Ugursal, 2006). However, only electricity/heating cogeneration has been considered most of the time although few studies can be found on electricity/heat/cold production using absorption units (Weber et al., 2006).

The aim of this paper is to explore the theoretical performances of natural gas fired fuel cell systems using adsorption-based systems for cooling. In the reformer/fuel cell system, various heat fluxes are available at different temperature levels (more than $300{ }^{\circ} \mathrm{C}$ for the reformer exhaust gases to $80^{\circ} \mathrm{C}$ for the PEMFC cooling loop for example). Hence, various options are 
available to drive the adsorption system. The adsorption system is designed as simple as possible (no heat/mass recovery) in order to minimize the capital cost and the complexity because of residential application.

This study presents a numerical investigation of the potential performance of such a system in terms of cooling capacity and COP but also in terms of volumic and specific cooling capacity. Three different adsorption pairs are considered (water/zeolite, water/silica gel, methanol/activated carbon).

\section{MODEL DESCRIPTION}

\subsection{Fuel Cell System}

The fuel cell system consists of the fuel cell coupled to the reformer where natural gas (NG) is converted to hydrogen. The energy inputs and outputs are represented on Figure 1 for a system tested at N-GHY facilities:

As it can be seen on figure 1, two heat sources can be used to drive an adsorption unit:

- The first one comes from the cooling loop of the fuel cell stack. However, the available power is limited $\left(3.7 \mathrm{~kW}_{\mathrm{h}}\right)$ and the temperature rather low $\left(65^{\circ} \mathrm{C}\right)$. Hence, this source will not be considered but it has to be pointed out that it could be used for hot water production in residential applications.

- The exhaust gases are the second available heat source. The temperature is high $\left(1026^{\circ} \mathrm{C}\right)$ as they come form the post-combustion unit where the remaining hydrogen, which was not used in the fuel cell, is burned. The gases composition is (\% volume 
basis): $\mathrm{N}_{2}$ (71.4), $\mathrm{CO}_{2}$ (11.2), $\mathrm{H}_{2} \mathrm{O}(17.2)$ and various trace gases (CO, $\mathrm{O}_{2}$, etc.) and the pressure is close to atmospheric.

The heat will be recovered from the exhaust gases by means of an intermediate heat exchanger (HX) between the adsorbers and the gas stream.

\subsection{Adsorption unit}

The adsorption unit is made of two adsorbers alternately connected to the evaporator or the condenser. The heat is recovered from the post-combustion exhaust gases thanks to the heat recovery heat exchanger $\left(\mathrm{HX}_{\mathrm{rec}}\right)$ while the heat rejection heat exchanger $\left(\mathrm{HX}_{\mathrm{rej}}\right)$ is used to reject the heat to the ambient. The basic cycle for refrigeration by adsorption with no mass or heat recovery is used to keep the system as simple and robust as possible. Hence, the adsorption cycle is divided into four steps: pre-heating, desorption, pre-cooling and adsorption. Whatever the adsorption pair, the components of the adsorption unit are the same (given geometry). They are presented on Figure 2 and their mathematical model described hereafter:

adsorption pair

Three adsorption pairs are tested (adsobent/adsorbate-refirgerant): activated carbon AC35/methanol, zeolithe 13X/water and silica gel RD/water. For the activated carbon AC35/methanol the Dubinin-Astakhov model is used (Passos, 1986 cited by Leite and Daguenet, 2000):

$$
\mathrm{q}=\mathrm{q}_{0} \cdot \rho_{\mathrm{l}}(\mathrm{T}) \cdot \exp \left(-\mathrm{D}\left[\mathrm{T} \cdot \ln \left(\frac{\mathrm{P}_{\mathrm{sat}}}{\mathrm{P}}\right)\right]^{\mathrm{n}}\right)
$$


where $\mathrm{q}_{0}$ is equal to $0.407 \mathrm{dm}^{3} / \mathrm{kg}_{\text {ads, }} \mathrm{D}$ to $3.2210^{-7} \mathrm{~K}^{-1}$ and $\mathrm{n}$ to 2.195 .

For the silica gel RD/water, the data given by Chua et al. (2002) are used. The authors used Toth model to predict the adsorption equilibrium:

$$
\mathrm{q}=\frac{\mathrm{K}_{0} \cdot \mathrm{e}^{\Delta \mathrm{H} / \mathrm{RT}} \cdot \mathrm{P}}{\left(1+\left(\frac{\mathrm{K}_{0}}{\mathrm{q}_{0}} \cdot \mathrm{e}^{\Delta \mathrm{H} / \mathrm{RT}} \cdot \mathrm{P}\right)^{\mathrm{t}}\right)^{1 / \mathrm{t}}}
$$

where $\mathrm{K}_{0}$ is equal to $7.3010^{-10} \mathrm{~kg} \cdot \mathrm{kg}_{\mathrm{ads}}{ }^{-1} \cdot \mathrm{kPa}^{-1}, \Delta \mathrm{H}$ to $48474 \mathrm{~J} \mathrm{~mol}^{-1}$ (isosteric heat of adsorption), $\mathrm{q}_{0}$ to $0.45 \mathrm{~kg} \cdot \mathrm{kg}_{\mathrm{ads}}{ }^{-1}$ and t to 12 .

For the 13X/water pair, a three term Langmuir equation is used (Ben Amar, 1993):

$$
q=\frac{\mathrm{q}_{0,1} \cdot \mathrm{b}_{1} \cdot \mathrm{P}}{1+\mathrm{b}_{1} \mathrm{P}}+\frac{\mathrm{q}_{0,2} \cdot \mathrm{b}_{2} \cdot \mathrm{P}}{1+\mathrm{b}_{2} \mathrm{P}}+\frac{\mathrm{q}_{0,3} \cdot \mathrm{b}_{3} \cdot \mathrm{P}}{1+\mathrm{b}_{3} \mathrm{P}}
$$

where $\mathrm{q}_{0,1}=\sum_{\mathrm{i}=1}^{3} \frac{\mathrm{a}_{\mathrm{i}}}{\mathrm{T}^{\mathrm{i}}} ; \mathrm{q}_{0,2}=\sum_{\mathrm{i}=1}^{3} \frac{\mathrm{c}_{\mathrm{i}}}{\mathrm{T}^{\mathrm{i}}} ; \mathrm{q}_{0,3}=0.374-\mathrm{q}_{0,1}-\mathrm{q}_{0,2} ; \mathrm{b}_{\mathrm{i}}=\mathrm{b}_{0, \mathrm{i}} \exp \left(\frac{\mathrm{E}_{\mathrm{i}}}{\mathrm{T}}\right)$

The value of the parameters $\mathrm{a}_{\mathrm{i}}, \mathrm{c}_{\mathrm{i}}, \mathrm{b}_{0, \mathrm{I}}$ and $\mathrm{E}_{\mathrm{i}}$ are given in Table 1 .

The sorption isosteres of the three pairs are plotted together on Figure 3.

adsorber

The heat exchanger of the adsorber consists of fins (aluminum) and tubes (copper). The outer dimensions are: height $0.27 \mathrm{~m}$, width $0.33 \mathrm{~m}$ and length $0.65 \mathrm{~m}$. The fin pitch is $7 \mathrm{~mm}$ corresponding with a total number of 78 fins. The total heat exchange area is $13 \mathrm{~m}^{2}$ and the 
inner volume is equal to $0.058 \mathrm{~m}^{3}$. The tube total mass is equal to $11.47 \mathrm{~kg}$ while it is $2.49 \mathrm{~kg}$ for the fins which corresponds to an overall $\mathrm{Mc}_{\mathrm{met}}$ equal to $6630 \mathrm{~J} . \mathrm{K}^{-1}$ per adsorber. The themal inertia of the adsorber shell is not taken into account as usually its temperature cycling is quite smaller than that of the heat exchanger and the adsorbent.

The temperature inside the adsorber is assumed homogeneous so that the energy balance during the desorption step is given by:

$$
\begin{aligned}
& \frac{\mathrm{d}}{\mathrm{dt}}\left\{\left(\mathrm{Mc}_{\text {met }}+\mathrm{Mc}_{\mathrm{ads}}+\mathrm{M}_{\mathrm{ads}} \mathrm{q}_{\mathrm{d}} \mathrm{C}_{\mathrm{p}, \mathrm{fl}}\right) \mathrm{T}_{\mathrm{d}}\right\}-\Delta \mathrm{H}_{\mathrm{fl}} \cdot \mathrm{M}_{\mathrm{ads}} \frac{\mathrm{dq}}{\mathrm{dt}}= \\
& \dot{\mathrm{m}}_{\mathrm{HW}} \mathrm{C}_{\mathrm{p}, \mathrm{HW}}\left(\mathrm{T}_{\mathrm{HW} \text {, in }}-\mathrm{T}_{\mathrm{HW} \text {, out }}\right)
\end{aligned}
$$

The outlet temperature of rejection fluid is calculated thanks to the following equation:

$$
\mathrm{T}_{\mathrm{HW}, \text { in }}=\mathrm{T}_{\mathrm{d}}+\left(\mathrm{T}_{\mathrm{HW}, \text { out }}-\mathrm{T}_{\mathrm{d}}\right) \cdot \mathrm{e}^{-\mathrm{UA}_{\mathrm{ads}} /\left(\dot{\mathrm{m}}_{\mathrm{HW}} \mathrm{c}_{\mathrm{p}, \mathrm{HWj}}\right)}
$$

During the adsorption step, the sensible heat to increase the vapour from the evaporation temperature to the adsorption temperature is taken into account. The mass flow rate of the heat rejection unit is assumed to be equally distributed between the condenser and the adsorber.

$$
\begin{aligned}
& \frac{\mathrm{d}}{\mathrm{dt}}\left\{\left(\mathrm{Mc}_{\text {met }}+\mathrm{Mc}_{\mathrm{ads}}+\mathrm{M}_{\mathrm{ads}} \mathrm{q}_{\mathrm{a}} \mathrm{c}_{\mathrm{pl}, \mathrm{fl}}\right) \mathrm{T}_{\mathrm{a}}\right\}-\Delta \mathrm{H}_{\mathrm{fl}} \cdot \mathrm{M}_{\mathrm{ads}} \frac{\mathrm{dq}_{\mathrm{a}}}{\mathrm{dt}}= \\
& \text { Mc }{ }_{\text {ads }} c_{p v, f l} \frac{d_{d}}{d t}\left(T_{e v}-T_{a}\right)+\frac{\dot{m}_{\text {Wrej }}}{2} c_{p} \text {, Wrej }\left(T_{\text {Wrej, out }}-T_{\text {Wrej, in }}\right)
\end{aligned}
$$

The outlet temperature of rejection fluid is calculated thanks to the following equation: 


$$
\left.\mathrm{T}_{\text {Wrej,in }}=\mathrm{T}_{\mathrm{a}}+\left(\mathrm{T}_{\text {Wrej, out }}-\mathrm{T}_{\mathrm{a}}\right) \cdot \mathrm{e}^{-\mathrm{UA}_{\text {ads }} /\left(\frac{\dot{\mathrm{m}}_{\text {Wrej }}}{2} \mathrm{c}_{\mathrm{p}, \text { Wrej }}\right.}\right)
$$

where

$$
\frac{1}{\mathrm{UA}_{\text {ads }}}=\frac{1}{\mathrm{~h}_{\text {Wrej } \mathrm{A}_{\text {Wrej }}}}+\frac{\mathrm{e}_{\text {ads }}}{\lambda_{\text {ads }} \mathrm{A}_{\text {ads }}}+\frac{1}{\mathrm{~h}_{\text {ads }} \mathrm{A}_{\text {ads }}}
$$

The values of heat transfer coefficient for the adsorbent can be found in the literature (Meunier, 1998, Poyelle et al., 1999, Chua et al., 2002) while the values for the cooling medium side were calculated. The different parameter values are reported for the different configurations in Table 2. The heating fluid is pressurized glycol-water for $\mathrm{AC} 35 / \mathrm{MeOH}$ and $\mathrm{RD} / \mathrm{H}_{2} \mathrm{O}$ systems, while oil (Therminol 66, SwanTek) is used for $13 \mathrm{X} / \mathrm{H}_{2} \mathrm{O}$ when the aim is to heat up the adsorber above $170^{\circ} \mathrm{C}$.

Thanks to its higher density, the silica gel RD loaded mass ( $40.2 \mathrm{~kg}$ ) is $50 \%$ and $28 \%$ higher than that of the AC35 $(26.7 \mathrm{~kg})$ and that of the $13 \mathrm{X}(34.2 \mathrm{~kg})$, respectively. This is of course a good point as the refrigerant mass depends directly on the adsorbent mass. However, this extra amount of adsorbent mass will increase the thermal inertia of the adsorbers: $+97 \%$ for the RD and $+52 \%$ for the $13 \mathrm{X}$ compared to the AC35.

As it can be seen as well, silica gel RD exhibits an overall heat transfer coefficient close to that of AC35 whereas it is about twice lower for the $13 \mathrm{X}$. This will impact directly the time to heat up or cool down the adsorber and hence the achievable cooling power. However, using oil instead of glycol water as secondary fluid has nearly no impact, which confirms that the heat transfer is limited by the adsorbate side in all cases.

\section{heat recovery heat exchanger $\left(\mathrm{HX}_{\text {rec }}\right)$}


In order to avoid hot spots in the adsorbers (which could be deleterious with the use of methanol as working fluid) it was chosen to use a gas/liquid heat exchanger to connect the adsorbers to the warm heat source. As the temperature on the gas side is high, it will be of parallel flow type. Considering the composition of the exhaust gas, the dew point temperature is about $58^{\circ} \mathrm{C}$ so that water condensation could not occur, $\mathrm{T}_{\text {gas,out }}$ staying above this value thanks to the parallel flow configuration. The outlet gas temperature $T_{\text {gas,out }}$ is calculated thanks to the following equation:

$$
\mathrm{T}_{\text {gas, out }}=\mathrm{T}_{\text {gas,in }}+\frac{\mathrm{T}_{\text {gas,in }}-\mathrm{T}_{\mathrm{HW} \text {,in }}}{\mathrm{r}} \cdot \psi_{\text {rec }}
$$

where

$$
\psi_{\text {rec }}=\frac{r\left(1-\mathrm{e}^{-\mathrm{m}}\right)}{\mathrm{r}-1} ; \mathrm{r}=-\frac{\dot{\mathrm{m}}_{\text {gas }}{ }^{\mathrm{c}} \mathrm{p}, \text { gas }}{\dot{\mathrm{m}}_{\mathrm{HW}}{ }_{\mathrm{C}}, \mathrm{HW}} ; \mathrm{m}=\frac{\mathrm{UA}_{\text {rec }}(1-\mathrm{r})}{\dot{\mathrm{m}}_{\text {gas }}{ }^{\mathrm{c}} \text {, gas }}
$$

Three values for $\mathrm{UA}_{\text {rec }}$ will be used: $25,50,100 \mathrm{~W} \cdot \mathrm{K}^{-1}$, which could be converted to heat transfer areas of $0.5,1$ and $2 \mathrm{~m}^{2}$ assuming an overall gas/liquid heat transfer coefficient of $50 \mathrm{~W} \cdot \mathrm{m}^{-2} \cdot \mathrm{K}^{-1}$.

\section{heat rejection heat exchanger $\left(\mathrm{HX}_{\text {rej }}\right)$}

The heat rejection unit is of air coil type, with no fan in order to minimize the electricity consumption of the unit. Hence, on the airside, free convection dominates the heat transfer with heat transfer area of $130 \mathrm{~m}^{2}$. The outlet temperature for the liquid is given by:

$$
\mathrm{T}_{\text {Wrej, out }}=\mathrm{T}_{\text {air }}+\left(\mathrm{T}_{\text {Wrej,in }}-\mathrm{T}_{\text {air }}\right) \cdot \mathrm{e}^{-\mathrm{UA}_{\text {rej }} /\left(\dot{\mathrm{m}}_{\text {Wrej }} \mathrm{c}_{\mathrm{p}, \text { Wrej }}\right)}
$$


The coefficient $\mathrm{UA}_{\text {rec }}$ is determined thanks to usual correlations for forced and free convection. Assuming a temperature pinch of $10 \mathrm{~K}$ and a temperature between 30 and $40{ }^{\circ} \mathrm{C}$ for the air, the average $\mathrm{UA}_{\text {air }}$ is $1066 \mathrm{~W} \cdot \mathrm{K}^{-1}$ if secondary fluid is glycol-water and only $900 \mathrm{~W} . \mathrm{K}^{-1}$ if oil is used.

\section{condenser}

For the condensation a plate heat exchanger is used. The plate height is $0.46 \mathrm{~m}$ with a width of $0.2 \mathrm{~m}$ and fourteen plates are used. The energy balance is written as:

$$
\begin{aligned}
& \frac{\mathrm{d}}{\mathrm{dt}}\left(\mathrm{Mc}_{\mathrm{cd}} \mathrm{T}_{\mathrm{cd}}\right)+\mathrm{L} \cdot \mathrm{M}_{\mathrm{ads}} \frac{\mathrm{dq}_{\mathrm{d}}}{\mathrm{dt}}= \\
& +\mathrm{M}_{\text {ads }} \mathrm{c}_{\mathrm{pv}, \mathrm{fl}} \frac{\mathrm{dq}_{\mathrm{d}}}{\mathrm{dt}}\left(\mathrm{T}_{\mathrm{cd}}-\mathrm{T}_{\mathrm{d}}\right)+\frac{\dot{\mathrm{m}}_{\text {Wrej }}}{2} \mathrm{c}_{\mathrm{p} \text {, Wrej }}\left(\mathrm{T}_{\text {Wrej, out }}-\mathrm{T}_{\text {Wcd, out }}\right)
\end{aligned}
$$

For the thermal inertia, only the metal mass is taken into account, all the fluid being stored in the evaporator $\left(\mathrm{M}_{\mathrm{cd}}=14 \mathrm{~kg}\right.$ and $\left.\mathrm{Mc}_{\mathrm{cd}}=5443 \mathrm{~J}_{\mathrm{kg}}{ }^{-1}\right)$. The temperature $\mathrm{T}_{\mathrm{Wcd}, \text { out }}$ is given by:

$$
\mathrm{T}_{\text {Wcd,out }}=\mathrm{T}_{\text {cd }}+\left(\mathrm{T}_{\text {Wrej,out }}-\mathrm{T}_{\text {cd }}\right) \cdot \mathrm{e}^{-\mathrm{UA}_{\mathrm{cd}} /\left(\frac{\dot{\mathrm{m}}_{\text {Wrej }}}{2} \mathrm{c}_{\mathrm{p}, \text { Wrej }}\right)}
$$

$\mathrm{UA}_{\text {cd }}$ is calculated thanks to the correlations given by Würfel and Ostrowski (2004) for the determination of the heat transfer coefficient on condensing and secondary fluid sides. Values for the different fluids are reported in Table 3 for a flow rate of $0.5 \mathrm{~kg} . \mathrm{s}^{-1}$ for the secondary fluid and a condensing temperature of $40^{\circ} \mathrm{C}$. 
Using methanol instead of water results in a heat transfer coefficient decrease of about $46-50 \%$, depending on the flow rate. As it will be seen in section 3, as the condenser geometry is given, the condensing temperature will be higher for $\mathrm{MeOH}$ than for water.

Thanks to early estimation of the refrigerant flow rate, its impact on the heat transfer coefficient was studied. Decreasing the refrigerant flow rate by a factor of 2.5 decreases the heat transfer coefficient by $26 \%$ for methanol and $19 \%$ for water. To take into account this parameter while keeping a rather simple model, a mean value will be used in the calculations.

Using oil instead of glycol water as secondary fluid lowers the performances by about $80 \%$. Again, this will result in higher condensing temperature.

evaporator

A tube and shell heat exchanger is used as evaporator (length: $1.5 \mathrm{~m}, 34$ tubes of $6 \mathrm{~mm}$ outer diameter and an inner diameter of $90 \mathrm{~mm}$ for the shell). It is equipped with a pump to recirculate the refrigerant. The chilled water return temperature $\mathrm{T}_{\mathrm{CW} \text {,in }}$ is assumed constant $\left(12^{\circ} \mathrm{C}\right)$ while the outlet temperature $\mathrm{T}_{\mathrm{CW} \text {,out }}$ will be determined thanks to an equation equivalent to eq. (16). The evaporator energy balance is given by:

$$
\begin{aligned}
& \frac{\mathrm{d}}{\mathrm{dt}}\left\{\left(\mathrm{Mc}_{\mathrm{ev}, \mathrm{M}}+\mathrm{MC}_{\mathrm{ev}, \mathrm{fl}}\right) \mathrm{T}_{\mathrm{ev}}\right\}+\mathrm{L} \cdot \mathrm{M}_{\mathrm{ads}} \frac{\mathrm{dq}_{\mathrm{a}}}{\mathrm{dt}}= \\
& +\mathrm{M}_{\mathrm{ads}} \mathrm{C}_{\mathrm{pl}, \mathrm{fl}} \frac{\mathrm{dq}_{\mathrm{d}}}{\mathrm{dt}}\left(\mathrm{T}_{\mathrm{ev}}-\mathrm{T}_{\mathrm{cd}}\right)+\dot{\mathrm{m}}_{\mathrm{CW}} \mathrm{c}_{\mathrm{p}, \mathrm{CW}}\left(\mathrm{T}_{\mathrm{CW}, \text { in }}-\mathrm{T}_{\mathrm{CW}, \text { out }}\right)
\end{aligned}
$$

Thanks to a recirculation pump the evaporation can take place on falling film mode, so that the correlations given by Liu et al. (2002) are used for the determination of $\mathrm{UA}_{\mathrm{ev}}$. The recirculation rate is taken equal to five and $\mathrm{UA}_{\mathrm{ev}}$ values are reported in Table 3. 
The same behaviour than for the condenser is found, with heat transfer coefficient decreased when using methanol instead of water. However, the decrease is only about 25-29 \% compared to nearly $50 \%$ for the condenser. In the same way, the impact of the mass flow rate is rather limited: between -10 and $-14 \%$. Hence, as for the condenser, average values will be used during the calculation.

\section{RESULTS}

The set of ODE/DAE is solved using DASPK 2.0 solver. Performances and operating temperature as a function of the half cycle time for the three adsorption pairs are reported in Figure 4 for the cooling power and COP and on Figure 5 for the chilled water and condensation average temperature (cycle basis) and for the maximum temperature reached in the adsorber (end of desorption step). For convenience, the reduced half-cycle time was used; it is equal to the ratio of the half-cycle time to the maximum one (2000 s for RD/ $\mathrm{H}_{2} \mathrm{O}$ and $\mathrm{AC} 35 / \mathrm{MeOH}$ and $4000 \mathrm{~s}$ for $\left.13 \mathrm{X} / \mathrm{H}_{2} \mathrm{O}\right)$.

From the three pairs, the silica gel $\mathrm{RD} / \mathrm{H}_{2} \mathrm{O}$ one appears to be the less competitive one. The maximum cooling power is $3.27 \mathrm{~kW}$ for a COP of 0.42 compared to $4 \mathrm{~kW}$ for $\mathrm{COP}=0.51$ and $3.78 \mathrm{~kW}$ for $\mathrm{COP}=0.52$ for $\mathrm{AC} 35 / \mathrm{MeOH}$ and $13 \mathrm{X} / \mathrm{H}_{2} \mathrm{O}$, respectively. This could be explained by the limited mass cycled because of isotherm characteristics. To highlight this point, the theoretical cycles obtained at maximum cooling power (i.e., the condensing and evaporating temperature are the averaged values given on figure 5) were plotted on figure 6 . For $\mathrm{RD}$ the amount adsorbed is equal to $38 \mathrm{~g} . \mathrm{kg}_{\text {ads }}{ }^{-1}$ at the end of the adsorption step and $8.8 \mathrm{~g} \mathrm{~kg}_{\mathrm{ads}}{ }^{-1}$ at the end of the desorption step. So, the corresponding cycled mass is almost equal to $30 \mathrm{~g} \mathrm{~kg}_{\mathrm{ads}}{ }^{-1}$. At

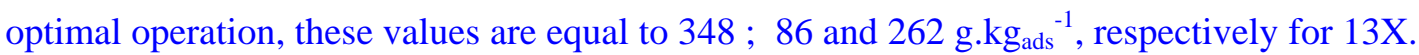
Hence, the ratio is about 8.7 in terms of cycle mass per $\mathrm{kg}$ of adsorbent. The higher density and global heat transfer coefficient of RD over $13 \mathrm{X}$ are not sufficient to overcome this aspect. It has 
to be noticed as well that RD is designed to work at low driving temperature (figure 6), which could explain as well its rather poor performance in our case.

The AC35/MeOH exhibits the greatest performances. However, as the adsorbent temperature should not exceed $130{ }^{\circ} \mathrm{C}$ because of component chemical stability, it is not possible to operate at maximum cooling power. Referring to Figure $5,130{ }^{\circ} \mathrm{C}$ is reached at the end of desorption step for a reduced half-cycle time of 0.45 (900 s). The corresponding cooling power and COP are $3.8 \mathrm{~kW}$ and 0.48 , respectively, which is still competitive compared to $13 \mathrm{X}$ performances. It should be noticed that the condensing temperatures are higher for AC35/MeOH compared to the two others: about $44{ }^{\circ} \mathrm{C}$ compared to $41^{\circ} \mathrm{C}$. This is directly linked to lower condensing heat transfer coefficient for methanol compared to water (cf. Table 3).

Concerning the $13 \mathrm{X} / \mathrm{H}_{2} \mathrm{O}$ pair, longer cycle times are needed in order to reach desorption temperature high enough to allow cold production. Hence, for the first reported cycle (half-cycle time of $800 \mathrm{~s}$ ) the temperature at the end of desorption step is worth already $125^{\circ} \mathrm{C}$ while the maximum cooling power is achieved for a temperature of $226^{\circ} \mathrm{C}$. For such high temperature, it is more suitable to use oil than pressurized glycol-water for secondary fluid. However, with oil, the heat transfer coefficients are smaller as it can be seen in section 2. The results are presented on Figures 7 and 8 for the three adsorption pairs for an external temperature of $40^{\circ} \mathrm{C}$.

The increase by $10 \mathrm{~K}$ of the air temperature has the following consequences:

- the installation with $\mathrm{AC} 35 / \mathrm{MeOH}$ cannot operate because end of desorption temperature above $130{ }^{\circ} \mathrm{C}$

- for $13 \mathrm{X}$ and $\mathrm{RD}$ the maximum cooling power is decreased by $11 \%$ and $22 \%$, respectively for COP values of 0.5 and 0.34 . 
- using oil instead of pressurized glycol-water results in a diminution by $11 \%$ of $13 \mathrm{X} / \mathrm{H}_{2} \mathrm{O}$ system performances. This is directly linked to the worst heat transfer coefficient for the condenser and the heat rejection unit: the condensation temperature increases by $10 \mathrm{~K}$ reaching $60^{\circ} \mathrm{C}$.

The influence of the global heat transfer coefficient for the heat rejection and heat recovery HXs' were addressed. The results for the maximum cooling power are presented in Table 4. The heat rejection unit appears to be the key element of the installation as it can severely limit the system performances: for example an increase of $38 \%$ of $\mathrm{UA}_{\text {rej }}$ allows increasing by 11 to $20 \%$ the cooling power for AC35/MeOH depending on $\mathrm{UA}_{\text {rec }}$ value. At given $\mathrm{UA}_{\text {rej, }}$, the interest of increasing $\mathrm{UA}_{\text {rec }}$ remains limited as it can result in performance degradation for $\mathrm{MeOH}$ (because of the maximum operating temperature at $130{ }^{\circ} \mathrm{C}$ ) or limited increase: for $13 \mathrm{X}$ at $\mathrm{UA}_{\text {rej }}=820 \mathrm{~W} / \mathrm{K}$, multiplying $\mathrm{UA}_{\text {rec }}$ by four increases the cooling power by only $5 \%$. From these results, it can be concluded that if the $\mathrm{AC} 32 / \mathrm{MeOH}$ delivers the highest cooling power $\left(3.96 \mathrm{~kW}\right.$ for $\mathrm{UA}_{\text {rej }}=1312 \mathrm{~W} / \mathrm{K}$ and $\left.\mathrm{UA}_{\text {rec }}=100 \mathrm{~W} / \mathrm{K}\right)$ it is more sensitive to the heat exchangers performances than the $13 \mathrm{X} / \mathrm{H}_{2} \mathrm{O}$. Indeed, its cooling power ranges from $3.28 \mathrm{~kW}$ to $3.96 \mathrm{~kW}$ while it ranges only from 3.55 to $3.82 \mathrm{~kW}$ for the $13 \mathrm{X}$. It means that the $13 \mathrm{X} / \mathrm{H}_{2} \mathrm{O}$ system will offer rather stable performances whatever the ambient outdoor temperature, which will make easier to meet the specification.

\section{CONCLUSION}

A model of a poly-generation installation based on a fuel cell system was built. This model takes into account the thermodynamic aspects but also heat transfer as they can easily limit the performances of an adsorption system. 
The AC35/MeOH offers the best performance in terms of cooling power and compactness.

However, a control system would have to control the maximum desorption temperature to avoid rapid degradation of the unit because of methanol dissociation. In all cases, the performances are highly sensitive to the performances of the heat rejection unit.

Hence, the best choice appears to be the $13 \mathrm{X} / \mathrm{H}_{2} \mathrm{O}$ system, which exhibits robust performances whatever the heat exchanger performance. Furthermore, the control of such a system will be easier than that of the AC35 one as there is no need to control precisely the adsorber temperature.

To go further, taking into account more precisely the temperature dependency of the thermophysics properties could enhance the model. This can have a high impact on heat transfer coefficient value. Furthermore, different strategies could be compared with the use of storage tank between the heat recovery HX and the adsorber in order to lower the driving temperature.

\section{Reference}

Ben Amar, N., 1993. Modélisation de pompes à chaleur à propagation de front de température, Ph. D. thesis, Université de Compiègne

Ben Amar, N., Sun, L.M., Meunier, F., 1996. Numerical analysis of adsorptive temperature wave regenerative heat pump, Applied Thermal Engineering, 16, 405-418

Chua, H.T., Ng, K.C., Chakraborty, A., Oo, N.M., Othman, M., 2002. Adsorption Characteristics of Silica Gel + Water Systems, Journal of Chemical Engineering Data 47, 11771181 
Leite, A.P.F., Daguenet, F., 2000. Performance of a new solid adsorption ice maker with solar energy regeneration, Energy Conversion Management 41, 1625-1647

Onovwiona, H.I., Ugursal V.I., 2006. Residential cogeneration systems: Review of the current technology. Renewable and Sustainable Energy Reviews, 10, 389-431

Lamari, M., Aoufi, A., Malbrunot, P., 2000. Thermal effect in dynamic storage of hydrogen by adsorption. AIChE Journal 46, 632-646

Liu, Z.-H., Zhu, Q.-Z., Chen, Y.-M., 2002. Evaporation heat transfer of falling water film on a horizontal tube bundle. Heat Transfer-Asian Research 31, 42-54

Meunier, F., 1998. Solid sorption heat powered cycles for cooling and heat pumping applications. Applied Thermal Engineering 18, 715-729

Passos, E.F., 1986, Etude des couples charbon-actif méthanol et leur application à la réfrigération solaire. Ph.D. Thesis, Federal Polytechnic College of Lausanne, Switzerland

Poyelle, F., Guilleminot, J.-J., Meunier, F., 1999. Experimental tests and predictive model of an adsorptive air conditioning unit. Industrial Engineering and Chemistry Research 39, 298-309

Weber, C., Maréchal, F., Favrat, D., Kraines, S., 2006, Optimization of an SOFC-based decentralized polygeneration system for providing energy service in an office-building in Tokyo. Applied Thermal Engineering 26, 1409-1419 
Würfel, R., Ostrowski, N., 2004, Experimental investigations oh heat transfer and pressure drop during the condensation process within plate heat exchangers of the herringbone-type, International Journal of Thermal Sciences 43, 59-68 


\section{Figure Captions}

Figure 1: Energy inputs and outputs of the fuel cell system

Figure 2: Description of the adsorption unit

Figure 3: Sorption isosteres of the three adorbent/adsorbate pairs: $\Delta$ Activated carbon

AC35/MeOH; $•$ Silica Gel RD/ $\mathrm{H}_{2} \mathrm{O}$ — Zeolite $13 \mathrm{X} / \mathrm{H}_{2} \mathrm{O}$

Figure 4: Evolution of cooling power and COP for different half-cycle times

Figure 5: Evolution of the operating temperatures for different half-cycle times

Figure 6: $\mathrm{RD} / \mathrm{H}_{2} \mathrm{O}(\bullet)$ and $13 \mathrm{X} / \mathrm{H}_{2} \mathrm{O}(\bullet)$ theoretical cycles based on averaged condensing and evaporating temperatures

Figure 7: Evolution of cooling power and COP for different half-cycle times with $\mathrm{T}_{\text {air }}=40^{\circ} \mathrm{C}$ Figure 8: Evolution of the operating temperatures for different half-cycle times with $\mathrm{T}_{\text {air }}=40^{\circ} \mathrm{C}$ 